\title{
A proposed vision for selecting the educational leadership in the youth centers in the light of the leading models and creativity in Assuit governorate *Dr/ Abdullah Farghaly Ahmed Khamees
} Abstract

The study objectives This study aimed to recognize:Recognizing the leadership styles which dominance between the employees at the youth and sportsdirectorate in Asyut To define the creativity level between the employees at the youth and sports directorate in Asyut And to achieve this the searcher used the disprctive method and it had been applied upon sample from 35 employees and mangaers at the youth and sports directorate and used a 2 questionnaire as follow:The first one aimed to define the leadership styles which dominance between managers of youth and sports directorate in AsyutThe second one aimed to define the creativity between managers of youth and sports directorate in AsyutAnd it had reach a results the important ones as follow -the weighed average of questioner axes and the whole form was 1.95 this average is fail in the medium achievement degree - the elements of creativity has a medium standard in the leadership at the youth and sports directorate in Asyut

key words creativity- leadership patterns - educational leadership

\section{The introduction and problem of the research:}

The educational process is considered the base in the process of guiding, organizing and coordinating the individuals' or the groups' efforts for achieving the individual's or the group goals. The educational leadership goes back to the time in which the social interaction begins and the work is distributed between the individuals and groups in various organizations and social systems. Accordingly, we find that the educational leader represents as an important and essential element in all stages of the

Assistant professor at the faculty of physical education- Assuit University

Assiut Journal For Sport Science Arts 
educational process, but the problem that faces the organizations now is the absence of the effective educational leader which became a rare commodity that we can not find easily (36-8). The educational leader occupies the main focus of the researchers and thinkers who tried, through their studies and researches, to analysis the leader's behavior and attitudes in all aspects, which in its turn provides us with a large amount of the scientific theories and the field studies which affected the attitude and the behavior if the educational leader and defined his concepts and hypothesis regarding his relation with his subordinates and his strategy in dealing with them (9-210).

In the light the situational educational theory developed by Blanchard \& Hessey, we can distinguish between the leadership models depending on the interaction between three factors (caring with people, caring with the production and the job maturity) as one of the most important factors of the situational theory with which the extent of success of the leading manner is determined with excluding the existence of a certain affective manner, since each situation has its own situation which is suitable for it. These four models are: the commanding leadership, the marketing leadership, the participating leadership and the authorization leadership (170$10)$.

Mohammed Hassan Allawy (1998) mentions that there are certain models that are used by the leaders during the leading process which can be noted easily. These models reflect the conduct and behaviors of the leaders clearly. These models are:

"the authoritative leadership, the autocratic leadership, the humanitarian leadership and non- interference leadership" (31-6), the matter which resulted in many problems which face the contemporary organizations. Accordingly, for solving these problems, we need to renounce the old traditional methods and to use new creative methods. This can not be done without finding the innovative individuals and providing the proper means that help in finding new methods and rapid administrative solutions. Thus, the innovation and creativity is 
one of the main educational components for the organizations (6-296).

For fulfilling the creativity process, there is a need for the potentialities necessary for the creativity and innovation. Whatever your innovative ability and the level of your knowledge, you can not get use of these abilities and powers and exploit them ideally if you don't work in cooperative and flexible environment and the noncreativity will be the outcome (2-49).

To develop the creativity, it is necessary to consider the requirements of the creative behavior which are represented in the organizational loyalty and belongingness, recognizing the economic and social relations between the individuals, following the scientific methodology to avoid the random one and interesting in the humanitarian element in the management, this in its turn increases the rate of performance, loyalty and belongingness to the organization and also this will increase the morals and job satisfaction which will make the employees rush upon their work and appear their creativity in the organization climate which encourages them to work (7-54).

The youth centers in Assuit governorate are important institutions in our contemporary life, since they work on upgrading the youth to face the scientific, sports, technical and the religious changes which the world lives. These centers also endeavor to prepare and provide the society with the human forces who have the advanced scientific experiences.

Through the researcher's observation, he found that there is a weakness in the level of the achievement by the leadership of the personnel at the youth centers. He also noted that there are few numbers of the youth who benefit from these centers since they abstain from the services and activities provided to them by these centers. All these factors affect negatively on the efficiency of the managing the youth centers.

It is known that the leadership models are one of the important factors that may help the subordinates to achieve the goals of the youth centers, which are part of the organization's goals as a whole. 
Accordingly, we are in dire need to the creativity and leadership by the personnel at the youth centers in the light of the current and contemporary conditions and as result of the economic, social, social, political and cultural changes. However, both the creativity and the educational leadership require a suitable administrative environment that encourages them and makes both the creativity and the educational leadership as a deep-rooted and renewable phenomenon for the personnel at the youth centers. Thus, the researcher has insisted on studying the relationship between the models of the leadership and creativity.

\section{The research goal:}

This research aims to "put a proposed vision for choosing the leaders of the youth centers in Assuit governorate in the light of the creativity and the models of leadership" through knowing the following:

1- The models of leaderships which are common between the personnel at the youth centers in Assuit governorate.

2- The level of creativity of the personnel at the youth centers in Assuit governorate.

3- The relationship between the creativity and the models of leadership of the personnel and manager of the youth centers in Assuit governorate.

The research questions:
1- What are models of leaderships which are common between the personnel at the youth centers in Assuit governorate?

2- What is the level of creativity of the personnel at the youth centers in Assuit governorate?

3- What is the relationship between the creativity and the models of leadership of the personnel and manager of the youth centers in Assuit governorate?

4- What is the proposed vision for choosing the leaders of the youth centers in the light of the creativity and the models of the leadership?

The plan and procedures of the research:

\section{The research methodology:}

The researcher has used the descriptive methodology (the surveying studies) with its procedures and steps because it is suitable for the nature and goals of the research.

\section{The research society:}

The research society included 117 youth centers on the level of Assuit governorate, including 350 individuals from the sports specialists who work as leaders and managers of these centers in Assuit governorate.

\section{The research sample:}

The research sample was chosen randomly, since an 
accepted number was chosen to form the research society. This number included managers of the youth centers and (15) of the personnel at the youth centers in Assuit governorate.

The tools of data collecting:

For collecting the data, the researcher has used the following tools:

The questionnaire: the researcher has designed (2) questionnaire forms which are distributed as follows:

The first questionnaire: it aims to recognize the models

Table (1)

the correlation coefficient between the degree of each axis and the total degrees of the questionnaire of the leadership models as a whole

\begin{tabular}{l|l|c|c|c}
\hline \hline Sr. & The axes & $\begin{array}{c}\text { The } \\
\text { mean }\end{array}$ & $\begin{array}{c}\text { Standard } \\
\text { deviation }\end{array}$ & $\begin{array}{c}\text { Value of } \\
\text { "R" }\end{array}$ \\
\hline \hline 1 & The democratic & r^.乏. & 10.01 & .99 \\
\hline 2 & The anarchic & r... & $1 r . V \vee$ & .99 \\
\hline 3 & The authoritative & ro.. & $1 r .0$. & .99 \\
\hline \hline
\end{tabular}

The value of $(\mathrm{R})$ at the significance level $(0.05=0.44)$.

Table (1) shows that there are correlation coefficients with a statistical significance between the degree of each axis and the whole axes of the questionnaire, since the correlation coefficients reached (0.99) and this indicates to the of leadership that are common between the personnel and managers of the youth centers. The second questionnaire: of the managers of the youth centers in Assuit governorate.

5- The scientific coefficients for recognizing the models of leadership:

a- The truth of the internal coherence between the degree of each axis and the total degrees of the first questionnaire: aims to recognize the creativity 
The researcher has used the application and re-application method for calculating the coefficient of stability for the questionnaire form. The application was conducted on (10) persons of the research society and out of the basic sample of the research with an interval reached (15) days.

Table (2)

the correlation coefficients between the first and second

application of the leadership models questionnaire $(\mathrm{N}=10)$

\begin{tabular}{|c|c|c|c|c|c|c|}
\hline \multirow{2}{*}{$\begin{array}{c}\text { Sr. } \\
1\end{array}$} & \multirow{2}{*}{\begin{tabular}{l}
\multicolumn{1}{c}{ The axes } \\
The \\
democratic
\end{tabular}} & \multicolumn{2}{|c|}{$\begin{array}{c}\text { The first } \\
\text { application }\end{array}$} & \multicolumn{2}{|c|}{$\begin{array}{l}\text { The second } \\
\text { application }\end{array}$} & \multirow{2}{*}{$\begin{array}{c}\begin{array}{c}\text { "R" } \\
\text { value }\end{array} \\
\cdot . \wedge 9\end{array}$} \\
\hline & & r^.乏. & 10.01 & r..Y. & $1 \leqslant .07$ & \\
\hline 2 & The anarchic & rı... & $I T . V V$ & TV.Y. & $1 \varepsilon .09$ & $.9 V$ \\
\hline 3 & $\begin{array}{l}\text { The } \\
\text { authoritative }\end{array}$ & ro... & 14.0. & $r \wedge . \wedge$. & $1 \pi . \varepsilon 1$ & .97 \\
\hline \multicolumn{2}{|c|}{ The whole form } & Vq. . . & $\varepsilon Y .0 Y$ & qY.Y. & $\S 1 . \wedge$ & .97 \\
\hline
\end{tabular}

The table value of $(\mathrm{R})$ at the significance level $(0.05=0.44)$.

Table (2) shows that there is a correlation with a statistical significance between the first and second application in the questionnaire of the leadership models, since the calculated value of $(\mathrm{R})$ ranged from (0.89 to 0.97) and it is larger than its table value at the level (0.05), and this indicates to the significance of the stability and reliability for the questionnaire axes.

The second questionnaire: the creativity of the managers of the youth centers in Assuit governorate:

- The scientific coefficients for the creativity questionnaire:

1- The truth of the internal coherence between the axes of the creativity questionnaire and its grand total:

Table (3)

the coefficients of correlation between the decree of each axis and the total degrees of the creativity questionnaire as a whole $(\mathrm{N}=10)$

\begin{tabular}{l|l|l|l|l}
\hline \hline Sr. & The axes & The mean & Standard & "R" \\
\hline \hline
\end{tabular}




\begin{tabular}{|c|c|c|c|c|}
\hline & & & deviation & value \\
\hline 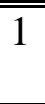 & $\begin{array}{c}\text { The educational } \\
\text { originality }\end{array}$ & Y.T. & 9.11 & .911 \\
\hline 2 & The flexibility & $r \cdot . \wedge \cdot$ & 1.70 & .99 \\
\hline 3 & The risk & 9.1. & $\varepsilon . Y \varepsilon$ & $\cdot .94$ \\
\hline 4 & The analytical ability & 9.1 . & $\varepsilon . \mu \varepsilon$ & .119 \\
\hline 5 & $\begin{array}{c}\text { The continuous } \\
\text { evaluation }\end{array}$ & $17 .$. & $\vee . \leqslant \varepsilon$ & .99 \\
\hline 6 & The social relations & $1 \leq . \cdots$ & 0.0 & .91 \\
\hline 7 & $\begin{array}{l}\text { The intellectual } \\
\text { fluency }\end{array}$ & $10 . \wedge$. & $7.9 \varepsilon$ & $.9 V$ \\
\hline
\end{tabular}

The table value of $(\mathrm{R})$ at the significance level $(0.05=0.44)$.

Table (3) shows that there are correlation coefficients with statistical significance between the degree of each axis and the axes of the questionnaire as a . (2)The reliability and stability whole, since the coefficients of correlations ranged from $(0.89$ to 0.99 ), and this indicates to the external coherence of the questionnaire

1- The stability of the form through the re-application method:

Table (4)

the correlation coefficients between the first and second application of the creativity form and the questionnaire as a whole $(\mathrm{N}=10)$

\begin{tabular}{|c|c|c|c|c|c|c|}
\hline \multirow[t]{2}{*}{ Sr. } & \multirow[t]{2}{*}{ The axes } & \multicolumn{2}{|c|}{$\begin{array}{c}\text { The first } \\
\text { application }\end{array}$} & \multicolumn{2}{|c|}{$\begin{array}{l}\text { The second } \\
\text { application }\end{array}$} & \multirow[t]{2}{*}{$\begin{array}{l}\text { "R" } \\
\text { value }\end{array}$} \\
\hline & & $\begin{array}{l}\text { The } \\
\text { mean }\end{array}$ & S.D & $\begin{array}{l}\text { The } \\
\text { mean }\end{array}$ & S.D & \\
\hline 1 & $\begin{array}{l}\text { The educational } \\
\text { originality }\end{array}$ & TI.T. & 9.11 & 11.7. & $1 \cdot . \leqslant Y$ & .94 \\
\hline 2 & The flexibility & $r \cdot \Lambda \cdot$ & 1.70 & $19 . \cdots$ & $1.1 \mathrm{~V}$ & $.9 \varepsilon$ \\
\hline 3 & The risk & $9 . \wedge$. & $\varepsilon . Y \xi$ & ᄉ. 7. & $\varepsilon .9 V$ & .9 . \\
\hline 4 & The analytical ability & $9 . \wedge$. & $\varepsilon . r \varepsilon$ & A.r. & $0 . Y V$ &. .10 \\
\hline
\end{tabular}

Follow Table (4)

the correlation coefficients between the first and second application of the creativity form and the questionnaire as a whole $(\mathbf{N}=10)$ 


\begin{tabular}{|c|c|c|c|c|c|c|}
\hline \multirow[t]{2}{*}{ Sr. } & \multirow[t]{2}{*}{ The axes } & \multicolumn{2}{|c|}{$\begin{array}{c}\text { The first } \\
\text { application }\end{array}$} & \multicolumn{2}{|c|}{$\begin{array}{l}\text { The second } \\
\text { application }\end{array}$} & \multirow[t]{2}{*}{$\begin{array}{c}\text { "R" } \\
\text { value }\end{array}$} \\
\hline & & $\begin{array}{l}\text { The } \\
\text { mean }\end{array}$ & S.D & $\begin{array}{l}\text { The } \\
\text { mean }\end{array}$ & S.D & \\
\hline$\overline{5}$ & $\begin{array}{l}\text { The continuous } \\
\text { evaluation }\end{array}$ & $17 .$. & $V . \leqslant \varepsilon$ & $1 \Gamma . \wedge$. & $\overline{c \Lambda . \Upsilon \wedge}$ & $\cdot .9 Y$ \\
\hline 6 & $\begin{array}{l}\text { The social } \\
\text { relations }\end{array}$ & $1 \leq .$. & 0.0. & IT.T. & $7 . r V$ & .90 \\
\hline 7 & $\begin{array}{l}\text { The intellectual } \\
\text { fluency }\end{array}$ & 10.1. & $7.9 \leq$ & $1 \leqslant . Y$. & $V . V T$ & .90 \\
\hline \multicolumn{2}{|c|}{ The whole form } & $1 \cdot \vee . \Lambda$. & $\varepsilon \varepsilon . V T$ & 90.7. & OY.YV & $.9 \mathrm{~V}$ \\
\hline
\end{tabular}

Table (4) shows that there is a correlation with a statistical significance between the first and second application in the creativity form, since the calculated value of $(R)$ ranged from (0.85 to 0.97) and it is larger than the table value of (R) at level (0.05), this indicates significantly to the stability of the questionnaire axes and the whole form.

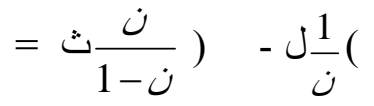

Since $(\mathrm{N})$ is the number of selections for one clause, $(\mathrm{L})=$ the largest repetition $\backslash$ the number of the sample individuals.

a- The stability of each axis of the form axes was calculated
The researcher has used the method of $b$ for calculating the stability of the scale after applying it to the exploratory sample, since $b$ is calculated from the equation (6)

$<\quad$ Calculating the stability of each clause of the form clauses through using the following equation:

by the mean of the clauses coefficients.

b- The stability of the whole form was calculated by calculating the mean of the axes' stability that form includes with knowing that the clause or axis becomes stable if $(\circlearrowleft)$ value is equal to or larger than $(0.19)^{3}$.

Table (5) 
the coefficients of the $b$ stability for the axes of the form and the form as a whole

\begin{tabular}{c|c|c|c}
\hline The axis & $\begin{array}{c}\text { Correlation } \\
\text { coefficient }\end{array}$ & The axis & $\begin{array}{c}\text { Correlation } \\
\text { coefficient }\end{array}$ \\
\hline \hline $\begin{array}{c}\text { 1-the educational } \\
\text { originality }\end{array}$ & $\cdot . \vee \vee$ & $\begin{array}{c}\text { 5- the continuous } \\
\text { evaluation }\end{array}$ & $\cdot . \Sigma 7$ \\
\hline 2- The flexibility &..$\varepsilon$ & $\begin{array}{c}\text { 6- the social } \\
\text { relations }\end{array}$ & $\cdot . \vee$ \\
\hline 3- The risk &.. or & $\begin{array}{c}\text { 7- the intellectual } \\
\text { fluency }\end{array}$ &. .79 \\
\hline $\begin{array}{c}\text { 4- the analytical } \\
\text { ability }\end{array}$ &. $.7 \%$ & & \\
\hline
\end{tabular}

The whole form $=0.60$

\section{Table (5) shows} coefficients of b stability for the form axes and the form as a whole.

The results of the study:

For achieving the research goals and answering is questions and in the light of the statistical analysis, the researcher tries to show, interpret and discuss the results as follows:

The results of the first questions:

For answering the first question, namely: What are the models of leadership that are common between the personnel at the youth centers in Assuit governorate?

First: the relative weights were calculated, then, the investigation level was defined for each clause and axis of the questionnaire axes, after that, the level of investigation was defined through the following equation:

The level of investigation= $(\mathrm{N}=1) \backslash \mathrm{n}$.

Since $(\mathrm{N})$ means the number of responses $(\mathrm{N}=3)$

The level of investigation $=(3-$

1) $\backslash 3=0.67$.

Table (6)

shows that extent of the response to each clause and axis of the questionnaire axes

Assiut Journal For Sport Science Arts 


\begin{tabular}{|c|c|c|c|}
\hline \multirow[b]{2}{*}{ The response } & \multirow{2}{*}{$\begin{array}{c}\text { The value } \\
\text { choosing each } \\
\text { clause (the weight) }\end{array}$} & \multicolumn{2}{|c|}{ The extent } \\
\hline & & from & To \\
\hline $\begin{array}{l}\text { The clause which indicates } \\
\text { the investigation with large } \\
\text { degree. }\end{array}$ & r & r & Tr. \\
\hline $\begin{array}{l}\text { The clause which indicates } \\
\text { the investigation with } \\
\text { middle degree. }\end{array}$ & r & r.r & 1.70 \\
\hline $\begin{array}{l}\text { The clause which indicates } \\
\text { the investigation with small } \\
\text { degree. }\end{array}$ & 1 & $1.7 \leq$ & $.9 V$ \\
\hline
\end{tabular}

First: the results of the total responses of the sample's individuals regarding the form and questionnaire of the leadership models:

Table (7)

shows weighing mean for the axes of the form and the form as a whole

\begin{tabular}{l|c|c}
\hline \hline \multicolumn{1}{c|}{ The axis } & $\begin{array}{c}\text { Correlation } \\
\text { coefficient }\end{array}$ & The order \\
\hline $\begin{array}{l}\text { The first axis: the democratic } \\
\text { axis }\end{array}$ & 1.66 & The third \\
\hline $\begin{array}{l}\text { The second axis: the anarchic } \\
\text { axis }\end{array}$ & 2.27 & The first \\
\hline $\begin{array}{l}\text { The third axis: the dictatorial } \\
\text { axis }\end{array}$ & 1.91 & $\begin{array}{c}\text { The } \\
\text { second }\end{array}$ \\
\hline The whole form $=1.95$
\end{tabular}

Table (7) shows the following:

- The mean of the weighing mean of the form axes and the whole form reached 1.95 , this mean lies in the investigation level with a middle degree, this result agrees to the results of the study conducted by Mohammed Bazegh Hamed (2006) (5) which indicated to that it is necessary to the managers to observe the absence and attendance of the personnel strictly with considering the necessary humanitarian conditions.

Assiut Journal For Sport Science Arts 
leadership model has occupied the first place with a mean of 2.27, whereas the axis which correlates to the dictatorial leadership model has occupied the second place with a relative weight of 1.91. Finally, the axis which correlates to the democratic model has occupied the last place with a relative weight of 1.66 .

This result agrees to the proofs and evidences which emphasize that the youth centers still suffering from the anarchy and negligence of

\section{Table (8)}

shows the weighing mean for the axes of the form and the whole form that correlates to the creativity

\begin{tabular}{c|c|c|c|c|c}
\hline \hline The axis & $\begin{array}{c}\text { Correlation } \\
\text { coefficient }\end{array}$ & $\begin{array}{c}\text { The } \\
\text { order }\end{array}$ & The axis & $\begin{array}{c}\text { Correlation } \\
\text { coefficient }\end{array}$ & $\begin{array}{l}\text { The } \\
\text { order }\end{array}$ \\
\hline \hline $\begin{array}{c}\text { 1-the } \\
\text { educational } \\
\text { originality }\end{array}$ & I.Or & $\begin{array}{c}\text { The } \\
\text { seventh }\end{array}$ & $\begin{array}{c}\text { 5- the } \\
\text { continuous } \\
\text { evaluation }\end{array}$ & The fifth & I.Vr \\
\hline $\begin{array}{c}\text { 2- The } \\
\text { flexibility }\end{array}$ & r.lv & $\begin{array}{c}\text { The } \\
\text { third }\end{array}$ & $\begin{array}{c}\text { 6- the } \\
\text { social } \\
\text { relations }\end{array}$ & The first & r.ro \\
\hline 3- The risk & r.lr & $\begin{array}{c}\text { The } \\
\text { fourth }\end{array}$ & $\begin{array}{c}\text { 7- the } \\
\text { intellectual } \\
\text { fluency }\end{array}$ & The second & r.r \\
\hline $\begin{array}{c}\text { 4- the } \\
\text { analytical } \\
\text { ability }\end{array}$ & I.TV & & & & \\
\hline
\end{tabular}

The whole form $=1.97$, the investigation with middle degree

Table (8) shows that the mean of the weighing mean of the form axes and the form as a whole is( 1.97), this mean lies in the level of investigation work as well as the rarity of obligation and compliance in executing the activities programs and overlooking the role that must be performed by the youth centers for developing the youth.

For answering the second questions: What is the level of creativity of the personnel at the youth centers in Assuit governorate?

Second: the results of the total responses of the sample individuals regarding the axes of the creativity form:

\footnotetext{
Assiut Journal For Sport Science Arts
} 
the elements of the administrative creativity (the fluency- the flexibility- the originality- feeling with the problems- the ability of analysis) are existed within the research's sample with a middle degree. The axis that correlates to the social relations has come in the first place with a mean of( 2.35), whereas the sample's responses to the axis which correlates to the intellectual fluency came in the second place. Finally, the axis that correlates to the educational originality came in the last place. These results are different from the results of the study conducted by Ghadeeb Mousa (2003) whose order was as follow: the flexibility, the ability of analysis, the originality, the feeling with the problems and the fluency.

For answering the third question: What is the relationship between the creativity and the models of leadership of the personnel and manager of the youth centers in Assuit governorate?, the researcher has studied the correlative relation between the degrees of the research sample in the two scales of creativity and the models of the leadership. For investigating the existence of relationship between the degrees of the research's sample in the two scales, Berson's correlation coefficient was used through the statistical program SPSS and the tables number (9) (10), which indicate the description of the sample and the matrix of the correlation coefficients between the two variables.

Table (9)

description of the sample's responses to the two variables of the research, namely, the creativity and the models of leadership

\begin{tabular}{|c|c|c|}
\hline The axis & $\begin{array}{c}\text { The mathematical } \\
\text { mean }\end{array}$ & $\begin{array}{l}\text { Standard } \\
\text { deviation }\end{array}$ \\
\hline The democratic axis & $17.7 \ldots$ & $T . \mu, T \leqslant 0$ \\
\hline The anarchic axis & $r \cdot . \Sigma \ldots$ & $Y . \wedge \varepsilon \cdot \wedge \wedge$ \\
\hline the dictatorial axis & IV.YYAT & Y.VIYOT \\
\hline The leadership scale & Oร.YYAT & $r . V \wedge r_{0}$ \\
\hline
\end{tabular}

Follow Table (9)

description of the sample's responses to the two variables of the research, namely, the creativity and the models of leadership 


\begin{tabular}{|c|c|c|}
\hline The axis & $\begin{array}{c}\text { The mathematical } \\
\text { mean }\end{array}$ & $\begin{array}{l}\text { Standard } \\
\text { deviation }\end{array}$ \\
\hline $\begin{array}{l}\text { The educational } \\
\text { originality }\end{array}$ & $1.01 \leqslant r$ & $1.18 Y 01$ \\
\hline The flexibility & IV.rEYq & T. .997r \\
\hline The risk & $1.710 \mathrm{~V}$ & $1.10 \mathrm{VTV}$ \\
\hline The analytical ability & $7.710 \mathrm{~V}$ & 1.TVTrM \\
\hline $\begin{array}{l}\text { The continuous } \\
\text { evaluation }\end{array}$ & $1.70 \mathrm{VI}$ & $1.54 r า 9$ \\
\hline The relations & $9 . \leqslant Y \wedge T$ & 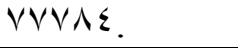 \\
\hline The intellectual fluency & M. & $r . \leqslant 01 \wedge 9$ \\
\hline The creativity scale & $V \tau . V I \leqslant r$ & T.OTAVV \\
\hline
\end{tabular}

Table (9) shows description of the sample's responses to the two variables of the research,

Table (10)

The matrix of Berson's correlation coefficients between the degrees of the research's sample in the scale of creativity and the models of leadership $\mathrm{z}$

\begin{tabular}{|c|c|c|c|c|}
\hline The dimensions & $\begin{array}{c}\text { The } \\
\text { democratic }\end{array}$ & $\begin{array}{c}\text { The } \\
\text { anarchic }\end{array}$ & $\begin{array}{c}\text { The } \\
\text { dictatorial }\end{array}$ & $\begin{array}{c}\text { leadership } \\
\text { scale }\end{array}$ \\
\hline $\begin{array}{l}\text { The educational } \\
\text { originality }\end{array}$ &. $.1 \mathrm{~V}$ & $* .19$ & $* * . \leqslant \mu_{-}$ & $\because 10$ \\
\hline The flexibility & $* * . . \leqslant V$ & $* *, . V Y$ & $* * . \wedge 9_{-}$ & $\cdot Y Y$ \\
\hline The risk & $\cdot . Y \varepsilon$ & $\because T^{\prime} Y_{-}$ & $\cdot Y \varepsilon_{-}$ & $\because V_{-}$ \\
\hline The analytical ability & **. §) & $* * . \wedge \Lambda_{-}$ & $* * . \wedge 0$ & *. \\
\hline $\begin{array}{l}\text { The continuous } \\
\text { evaluation }\end{array}$ & .19 & $* * \cdot V \Gamma$ & $* * . .0 \Lambda_{-}$ & *.M \\
\hline The relations &. $.1 T$ &.$Y T$ & $* * . . \leqslant 0_{-}$ & $\because 91-$ \\
\hline $\begin{array}{l}\text { The intellectual } \\
\text { fluency }\end{array}$ & $. .11-$ & $* * . .0 \Lambda_{-}$ & $* * . .01$ & $\because 1 \cdot r_{-}$ \\
\hline The creativity scale & $* . \mu_{0}$ & $\because \cdot 7$ & $* * . . q_{-}$ & $\because \mu_{-}$ \\
\hline \multicolumn{2}{|c|}{$\begin{array}{l}\text { * It is significant at level }(0.05,) \\
\text { since the table value of } \\
\text { Berson's coefficient at the level } \\
\text { reached }(0.27) \text {. }\end{array}$} & \multicolumn{3}{|c|}{$\begin{array}{l}\text { ** It is significant at level( } \\
0.01) \text {, since the table value of } \\
\text { Berson's coefficient at the level } \\
\text { reached }(0.38) \text {. }\end{array}$} \\
\hline
\end{tabular}


Table (10) shows that following:

1- The democratic model correlates positively with statistical significance to the flexibility dimension, and it correlates negatively with a statistical significance to the dimension of the analytical ability.

2- The anarchic model correlates positively with a statistical significance to the dimensions of the educational originality, the flexibility and the continuous evaluation. The anarchic model correlates negatively with a statistical significance to the dimensions of the analytical ability and the intellectual fluency.

3- The dictatorial model correlates positively with a statistical significance to the dimensions of the analytical ability and the intellectual fluency of the creativity scale. It correlates negatively with a statistical significance to the dimensions of the flexibility, the continuous evaluation, and the relations on the creativity scale.

4- The scale of the leadership models correlates positively with a statistical significance to the dimension of the continuous evaluation of the creativity scale, and correlates negatively with a statistical significance to the dimension of the analytical ability.

\section{The conclusions}

In the light of the leadership models:

1- The weighing mathematical mean of the form axes and the whole form is (1.95); this mean lies in the investigation level with a middle degree.

2- $\quad$ The axis of the anarchic leading model has come in the first place with a mean (2.27), whereas the samples' responses to the axis of the dictatorial model have occupied the second place with a relative weight (1.91.) Finally, the axis of the democratic model has occupied the last place with a relative weight of (1.66).

3 - The managers in the youth centers practice the anarchic model, followed by the dictatorial model and the democratic model. All these models are practiced with a middle degree.

\section{In the light of the creativity,}

1- The creativity elements are practiced with a middle degree by the managers of the youth centers in Assuit governorate. 


\section{1}

2- The mean of the weighing mean for the form axes and the whole form is (1.97); it lies in the investigation level with a middle degree.

3- The axis that correlates to the social relations has come in the first place with a mean of (2.35), whereas the sample's responses to the axis which correlates to the intellectual fluency came in the second place. Finally, the axis that correlates to the educational originality came in the last place.

In the light of the relationship between the models of leadership and the creativity:

1- The democratic model correlates positively with a statistical significance to the flexibility dimension and the central degree on the creativity scale; it correlates negatively with a statistical significance to the dimension of the analytical ability.

5- The anarchic model correlates positively with a statistical significance to the dimensions of the educational originality, the flexibility and the continuous evaluation. The anarchic model correlates negatively with a statistical significance to the dimensions of the analytical ability and the intellectual fluency.

\section{2- The dictatorial model} correlates positively with a statistical significance to the dimensions of the analytical ability and the intellectual fluency of the creativity scale. It correlates negatively with a statistical significance to the dimensions of the flexibility, the continuous evaluation, the relations and the central degree on the creativity scale.

4- The scale of the leadership models correlates positively with a statistical significance to the dimension of the continuous evaluation of the creativity scale, and correlates negatively with a statistical significance to the dimension of the analytical ability.

5- There is a positive correlative relationship between the models of leadership (the democratic model, the anarchic model and the dictatorial model) and the level of the creativity of the leadership in the youth centers.

The shortcomings in the models of leadership:

- Some managers of the youth centers allow some 
personnel at the submanagement of the sports and youth directorate to go out during the work hours and this affect negatively to the performance of the personnel and the management as a whole.

- Some managers of the youth centers deal easily with the personnel who neglect their work.

- Some managers in the youth centers ignore the organizational regularities for the educational work inside the center.

- Some managers in the youth centers consider that the discussion and dialogue is a time-waste and this affects negatively on the development of the creativity aspects, in particular the axis of the analytical ability.

- Some managers in the youth centers ask the specialists to execute the plan without contributing in its accuracy, this affects negatively in the future on the development of the continuous evaluation for the sports specialists who work in the youth centers.

The strength points in the models of leadership
- Some managers in the youth centers share the youth members in putting the plan of the centers and this makes the members recognize the extent the plan importance and how to execute it easily as well as developing the spirit the educational originality of the personnel.

- The participation in expressing the opinions of the personnel and the specialists help in planting the principal of the intellectual fluency in creating new ideas that are suitable for the current situation.

- Some managers in the youth centers assign their powers to some personnel in making the decisions and solving the problems they face. This affects positively on the personnel who face some risks and challenges for improving the level of the management work.

The shortcomings in the creativity

- Some personnel at the branch management of the sports and youth directorate hesitate in applying the new methods fearing of the failure and bearing the work responsibility. 
- $\quad$ Some personnel abstain from suggesting some alternative solutions for the personnel in the case of the weak probability of their success.

The aspects of strength in the creativity:

- Some personnel concern with providing the proposal to the managers.

- Getting the new ideas and proposals which contribute in solving the problems.

- Examining the problems which face the youth centers from different aspects for finding the proper solutions for facing the problems in the light of the alternative solutions.

- $\quad$ Some personnel insist on applying the ideas which were previously applied to face a certain problem.

- Insisting on knowing the opinion that is different from the opinions of some personnel and knowing the suitable ones.

For answering the fourth question: What is the proposed vision for choosing the leaders of the youth centers in the light of the creativity and the models of the leadership?
The study tries to answer this question through the following proposal:

- The proposed vision for selecting the educational leadership of the youth centers in the light of the models of leadership and creativity.

The concept of the proposed vision:

Activating the role of the leaders of the youth centers and activating their roles in the work.

The goal of the proposed vision:

Putting a proposal and vision for selecting the leaders of the youth centers in the light of the goals put by the directorate of youth and sports in Assuit governorate.

The stage of preparation for selecting the educational leadership in the light of the creativity:

When: if the manger position was vacant in some of the youth centers.

Where: inside the branch management of the youth and sports directorate in the youth centers.

Who is the applicant: the sports specialists at the branch department of the youth and sports directorate. 
Who performs the selection process?

- A committee with an experience in the work at the branch management which consists of (3) persons and under the presidency of the ministry agent at the directorate of youth and sports in the governorate (who supervises the youth centers in the governorate) and the membership of the dean of faculty of physical education and one of the experts in the centers' field.

The conditions and mechanisms of executing the proposed vision:

1- The functional record which witnesses with the obligation and integrity.

2- The interview with the decision makers.

3- The educational efficiency which includes:

4- The various educational experiences

5- The skills of the strategic planning and putting the budgets of the directorate.

6- $\quad$ The ability to provide a democratic climate inside the directorate which encourages the innovation and creativity.

7- The skills of communication with the youth, the teaching staff, the managers of the youth centers, the sports specialists and the personnel at the directorate.

8- The skills of time management.

9- The skills of crises management

10- The ability to get use of all concerned parties for developing the directorate.

\section{4- The scientific efficiency}

- Dealing efficiently with the computer.

- $\quad$ Speaking one foreign language well and it is preferred to speak another language.

- $\quad$ Presenting a proposal for the work inside the directorate and the way of developing the sector concerned with the job.

- Getting training courses in (preparing the leaders-the communication skills- the time management- the crises management- the planning).

5- The positive interaction in the center's activities and the directorate of youth and sports in Assuit through the following:

- The participating in the public projects issued by the directorate of youth and sports in Assuit.

- Executing the annual plan for the activities of the Assiut Journal For Sport Science Arts 
youth centers and the directorate of youth and sports in Assuit governorate.

6- The specialists' opinions regarding the character of the candidate for the job.

7- $\mathrm{He}$ must play an important role and activity in the field of the youth centers.

8- He must still in the work (at the center or at the directorate of youth and sports in Assuit for two or three consecutive years at least and he must have high certificate).

\section{The following up and} evaluation:

- Following up the plan of the center in the field of the youth activities.

- Following up the investigating the subjective plan.

- The rate of achievement in the light of the comprehensive quality which is attached to the documents in each term.

- Evaluating the satisfaction of the subordinates to the performance of the educational leader.

- Recognizing the points of strength and weakness of the trainers and the specialists.

The recommendations:
- The necessity of activating the role of the leaders at the youth centers in developing the skills and the educational creative abilities of their subordinates.

- Working on establishing clear standards accepted by the directorate of youth and sports in selecting the leaders of the youth centers in Assuit governorate.

- Providing the moral, physical, technical and technological facilities for helping in the process of change and executing it by the directorate of youth and sports in Assuit governorate.

- Paying attention to the personal and scientific needs and providing them with the opportunity to participate in building the future visions for their institutions.

- Using the positive incentives and the punishment if the need is to be.

- Allowing the subordinates to participate in making the decisions and to recognize their abilities in achieving the goals of the directorate in Assuit governorate.

- Demonstrating the spirit of friendship in the work by which the subordinates realize 
that the managers of the youth centers know and understand their problems and their point of views.

- $\quad$ Creating the spirit of the team between the personnel at the branch department and the directorate of youth and sports, since the team coherence helps in achieving the progress.

- Evaluating the performance of the personnel at the branch department and the directorate of youth on subjective bases without favoritism.

\section{The references}

1- Abdullah Al Sayed

Abdel Gawad "the educational indicators and using the mathematics in the human sciences", Assuit- Library of Golden Fingers 1983.

2- Abdel Rahman Tawfiq "the methodology of the higher management in thinking", Cairo- the center of the professional experiences 2004. 3- Abdel Sabour Mansour Mohammed: "the relationship between the personal characteristics and the ability to solve the problems that face the excellent Saudi and Egyptian students- Journal of the education future- Edition 44- 2007.

4- Fouad Al Bahy Al Sayed "The statistical psychology and measuring the human mental"- Cairo- The house of the Arab Thought.

5- Mohammed Bazeegh Hammed "the transforming leadership and its relation to the administrative creativity"Master dissertation- Nayef University for the Security sciences 2006.

6- Mohammed Hassan Allawy "The psychology of the trainer and the sports training"Cairo 1999.

7- Nawaf Al Mottery "The organizational education and developing the creativity skills according to the opinions of the passports' officers in Mecca"- Master dissertationUm Al Qura- Mecca 2005. 